\title{
LEGAL NORMS, PROFESSIONAL VALUES, AND PRACTICAL ETHICS IN LOCAL GOVERNMENT: ELDERLY CARE IN LATVIA, LITHUANIA, AND NORWAY
}

\author{
NORMAS LEGALES, VALORES PROFESIONALES Y PRÁCTICAS ÉTICAS \\ EN EL GOBIERNO LOCAL: EL CUIDADO DE PERSONAS MAYORES EN \\ LETONIA, LITUANIA Y NORUEGA
}

Monica Kjørstad
Oslo and Akershus University College of Applied Sciences. Oslo. Noruega/Norway
Harald S. Koht
$\begin{array}{r}\text { Harald.Koht@hioa.no } \\ \text { Oslo and Akershus University College of Applied Sciences. Oslo. Noruega/Norway } \\ \text { Latvia University. Riga. Letonia/Latvia } \\ \text { Iveta.Reinholde@lu.lv } \\ \text { Geir C. Tufte } \\ \text { Østfold University College. Halden. Noruega/Norway } \\ \text { geir.c.tufte@hiof.no }\end{array}$

Recibido/Received: 12/04/2016

Modificado/Modified: 30/9/2016

Aceptado/Accepted: 2/10/2016

\begin{abstract}
This article reports findings from a comparative study of the influence of values and norms on the delivery of administrative and professional services in the public sector at the local government level in three selected countries in the Baltic Sea Region, Latvia, Lithuania, and Norway. The research concerns the criteria that professional welfare and health professionals apply in individual cases whenever they are expected to make high-quality judgments regarding the care of older people. The research question seeks to explore whether there are significant differences with regard to the effect of formal rules and norms on the effort to arrive at good solutions in providing public services in three democracies, one long-established and two recent.

The results of this study show that in making their decisions, professionals in all countries emphasize the necessity of considering a broad range of legal and professional norms. For all respondents these considerations - in varying degrees of intensity - rank ahead of economic and administrative concerns.
\end{abstract}

\section{KEYWORDS}

Aging population, care for older people, Latvia, Lithuania, Norway, norms, values.

\section{CONTENTS}

1. A challenge for all: Introduction. 1.1. Aims and Objectives. 1.2. Social Norms and Discretion. 1.3. Multidimensional Design: A Cross-National Policy Comparison. 2. Method/data sources. 2.1. The 
Vignette Method. 2.2. Considerations in Deciding Individual Cases. 3. Results. 4. Conclusion. 5. Acknowledgments. References.

\section{RESUMEN}

Este artículo presenta los resultados de un estudio comparativo de la influencia de los valores y las normas sobre la prestación de servicios administrativos y profesionales en el sector público a nivel de los gobiernos locales en tres países seleccionados de la región del Mar Báltico, Letonia, Lituania y Noruega. La investigación se refiere a los criterios que aplican los profesionales de la Administración y de la Salud en casos individuales en los que siempre se espera que se hagan evaluaciones con un alto grado de profesionalidad por tratarse del cuidado de las personas mayores. La pregunta de investigación busca explorar si existen diferencias significativas respecto al efecto de las reglas y normas formales sobre el esfuerzo a realizar para llegar a buenas soluciones en la prestación de servicios públicos en tres democracias europeas, una consolidad desde hace tiempo y dos recientes.

Los resultados de este estudio muestran que en la toma de decisiones, los profesionales en los tres países hacen hincapié en la necesidad de considerar una amplia gama de normas legales y profesionales. Para todos los encuestados estas consideraciones -en diferentes grados de intensidad- las sitúan por delante de los intereses económicos y administrativos.

\section{PALABRAS CLAVE}

Envejecimiento de la población, la atención a las personas mayores, Letonia, Lituania, Noruega, normas, valores.

\section{SUMARIO}

1. Un desafío para todos: introducción. 1.1. Objetivos y propósitos. 1.2. Normas sociales y discreción. 1.3. Diseño multidimensional: una comparativa transversal de políticas nacionales. 2. Método y fuente de datos. 2.1 Método de la viñeta. 2.2. Consideraciones para decidir los casos individuales. 3. Resultados. 4. Conclusiones. 5. Reconocimientos. Bibliografía.

\section{A CHALLENGE FOR ALL: INTRODUCTION}

Lengthening the human life span is one of the great achievements of the past century. It has resulted in an increase in the aging of the population and in the number of people in need of care. Together with structural and normative changes in the family, this trend has increased demands on the welfare services and required an increasing share of public resources. As a policy area, care for the elderly has become an urgent challenge and specific solutions have been developed in many countries. This article presents a comparison of the norms and concerns that distinguish the social services for older people in three countries: Norway, Latvia and Lithuania.

In Norway, as in other Scandinavian countries, the 1960s and early 1970s accommodated an expansion of both access and standards in nearly all kinds of services for the aged. The 1990s showed nevertheless a tendency towards a decline in accessibility to most services (Daatland, 1997). This retrenchment has continued with the growing number of elderly and the inclination of wage earners to increase spending on children rather than on older people (Sørensen, 2009, Gregersen \& Melberg, 2014).

Correspondingly, the economic recession beginning in 2008 affected elderly care in Latvia and Lithuania negatively. All Baltic countries faced a sharp decrease in access to public services for all social groups, including health care and social services for the elderly (Peters et al., 2011). However, the recovered economy after the recession did not improve the sense of security among the general public. The main concerns of elderly continue to be related to 
the fear of serious illness and low pension income prospects (SKDS, 2012). The two concerns are connected since low pensions imply fewer resources for health care, while any serious sickness means redistribution of scarce resources.

This study compares policies towards the elderly at the local government level. In particular the study focuses on the norms that prevail when professional social workers and health workers at the front level make assessments and decisions about care for the oldest people in our societies. We wish to elaborate and discuss to what extent do professionals possess autonomy to make discretionary assessment and the role of family or network participation in the decision process about the care for older family members and if there any differences between public administrators' ability to act in those cases.

\subsection{Aims and Objectives}

The aim of this article is to:

a) Examine the values, norms, and practical ethics that dominate decision-making in the care of older people in Latvia, Lithuania, and Norway

b) Explore and analyze similarities and differences regarding the practical implementation of services at the local government level

Our research questions are:

1) Which particular norms influence the decisions made by the professionals working with care for older people in the three countries?

2) Are there any differences between the countries according to the norms that predominate: legal norms, professional values, or situational/personal ethics?

3) To what degree is the front-line administrator allowed to exercise professional discretion, and does the norm structure present ethical dilemmas?

Welfare is considered as 'social welfare' that can be defined as a 'range of services provided by the state' (Spicker, 1995: 54). This perspective includes services that deal with older people's personal needs: residential care, including specialized accommodation; domiciliary care (home help care) and day care for older people. Older people is defined as the proportion of the population older than 65 years $(65+)$. Every country is defined as a single case: the Norwegian case, the Latvian case, and the Lithuanian case.

We do not work with a hypothesis in this study. The purpose is to explore the phenomenon in order to contribute to new insight.

\subsection{Social Norms and Discretion}

In professional discourse, the application of universal ethical rules is challenged as a guide for action. The main argument against such an application is that the ethical and moral choices made by professionals always depend on the local situation. On the other hand universal rules or codes are proclaimed as necessary to guard against breaches of generally accepted norms, to secure basic rights, and to ensure the appropriate use of professional power, as argued by James H. Svara (2014).

This dispute concerns fundamental problems related to the role of professions in the welfare state. In their practical work, public administrators have to make decisions based upon professional judgements that fall between these two opposing claims (Kjørstad, 2015; 2005). This is the field where administrative discretion takes place. Situations may arise where professionals must make decisions in the face of openly conflicting interests, for example between meeting the obvious needs of the client and loyalty to administrative or political policies. In those cases, the public administrator will face ethical dilemmas, i.e. 
situations that are dominated by doubt and ambivalence, where the alternatives at hand are unsatisfactory. The ethical dimension becomes acute whenever conflicting interests are involved, or whenever contradictory ethical norms are pitted against one another (Eriksen, 2001). Hydén (2011) posits that individuals must make a trade-off between norms, available knowledge, and factual possibilities for implementation.

\subsection{Ethical Relations}

Public administrators, whether as social workers or other kinds of professionals, must engage in a number of relationships with potential ethical conflict: relationships to clients, colleagues, employers, politicians, and the public at large. How these relationships may influence their assessments and decisions at the practical level has been well described and analyzed in empirical studies (Kjørstad 2015; 2005, Lundquist 1988, Rothstein 2001). The concept of role expresses the particular way that formal organizations authorize professionals to act and limits and circumscribes their freedom to act. In this way, the professional role serves as a constraint for the encounter between the personal morality of the administrator and the morality of the organization and the bureaucratic chain of command.

The late Swedish political scientist Lundquist (2001) pointed out three relationships that can generate ethical dilemmas for public administrators, who aim to uphold professional values:

a) The public administrator has a bond of loyalty to superiors

b) The public administrator uses diverse means to exercise authority, including possibilities for the use of coercion.

c) The public administrator works within a context that is dominated by democratic processes and substantial values that he or she must take into consideration as an official and as a citizen.

Here we will focus on some general norms and values of public administration, and the multifunctional concerns of public organizations. In using the concept public ethos, Lundquist (1998) claims that the public administrator must consider and balance two main sets of values: democratic values and economic values. Democratic values are political democracy, public ethics and the rule of law. Economic values are functional rationality, cost-efficiency and productivity.

Social norms can be understood by the manner in which political institutions structure the decision-making situation faced by actors and how they influence trust (Rothstein, 1998). Norms can also be explained in the opposite way: as the fundamental directives for institutional decision-making and proper use of administrative discretion. This type of discretion is generally defined as the exercise of professional expertise and judgement, as opposed to strict adherence to regulations or statutes, in making a decision or performing official acts or duties (West, 2004).

A discretionary action is informal and, therefore, unprotected by the safeguards inherent in formal procedure. A public official, for example, has administrative discretion when he or she has the freedom to make a choice among potential courses of action (West 2004).

Autonomy is often explained as a human right, which everyone deserves. (Dworkin, 1988; Kildal \& Kuhnle, 2005; Rawls, 1993). The autonomy of a public administrator consists of two components: freedom to act and ability to act (Lundquist, 1988; Lundquist, 2001). Freedom to act (e.g. the occasion to make decisions based on discretion) makes it possible for public administrators to make decisions, to some extent, based on their own priorities. Ability to act is the objective capacity of the administrators to use that freedom to act, for 
example by having the necessary economic resources to implement a decision. Both components have to be present for the public administrator to be autonomous.

Another way to document autonomy in discretionary reasoning by public officials can be found in applying a stage model of moral reasoning developed by Stewart, Sprinthall \& Siemienska (1997: 448):

1. Concern for obedience and punishment.

2. Concern for cooperation and reciprocity in a single instance.

3. Concern for enduring relationships.

4. Respect for law and duty.

5. Concern for abstract principles of societal cooperation.

The authors regard ethical reasoning at level five as the most principled or universal stage; they also expect to find an emphasis on ethical principles as a basis for decision-making in countries in democratic transition (445). However, reasoning at levels one through three represents risks of arbitrariness, shirking and corruption.

While many bureaucrats in public administration have restricted autonomy within limits set by legislators, the traditional norms that define the role of bureaucracy as an obedient tool of policy makers, have been considerably challenged by political scientists (Rothstein, 2001), while the legal scholar Hydén (2011) points at "the rigidity that can characterize the maintenance and application of rules." At a time when market liberalism and New Public Management discourse have gained increased influence and are even accepted as political premises for social work and similar welfare professions (Taylor \& Kelly, 2006: 632), we are justified in asking whether or not ethical dilemmas are built into the positions that are occupied by public servants. In this connection, the construct "common morality" (in Norwegian: allmenmoral) has relevance. "Common morality" has two basic components (Tranøy, 1998). There are norms (obligations, prohibitions, rights, rules and laws, ethical codes) and values (good and evil, the consequences of action or inaction). A personal selection of moralities and the capacity to be morally creative are the ingredients of this concept.

The advantage of common morality is that it lacks any precise formulations. It opens up a free normative space between the legal and the moral order (Tranøy, 1998). Following the rationale of Tranøy, professionals are performing their duties in the free normative space that opens up when the legal code accepts professional discretion.

\subsection{Comparing Welfare Systems}

Combining qualitative interviews with a questionnaire based on quantifiable, normative variables, we have collected reflexive data about how the care of older people is practiced in three countries. Normative knowledge of both policy makers as well as practitioners is dependent on dominant moral and ideological discourses that might be more or less institutionalized. Public policies include coordinated decisions and actions of policy makers aimed at solving policy problems by adjusting social and economic systems to pressures from the environment.

This approach has an aspect of being institutional in the sense that we take into consideration that Norway has strong and long-lived institutions of the Social Democratic type, which embed the country within the normative position of a generous welfare state. The fact that the Nordic countries have long traditions of liberal democratic institutions, entrench the authorities in a frame of stable and non-revolutionary decisions. Latvia and Lithuania, on the other hand, do not yet have institutions that limit their policies to the same degree. Both 
Baltic countries are still young liberal democracies, having until 1991 experienced five decades of quist 1997) authoritarian rule as integral parts of the Soviet Union.

Comparative data on care for older people are not sufficiently available in international data sources. Not surprisingly, there are no official sources of quantitative or qualitative data available to be used for direct comparison of welfare systems in Latvia, Lithuania and Norway (Guogis \& Koht, 2009: 151). What is available is described in different languages and formats. To do a comparative study of the three countries therefore demands in-depth knowledge of the policy areas and sufficient knowledge about each country's historical context.

Figure 1 illustrates the multidimensional design that includes the dynamic relations between the structural, the discursive and the practical aspects of this research. Legal norms, institutional norms, professional norms, and contextual data are interwoven and overlapping.

\subsection{Multidimensional Design: A Cross-National Policy Comparison}

Recent articles have reviewed the challenges represented by comparative studies of public administration. Jody Fitzpatrick et al. (2011) point to methodological limitations, cultural issues, and the problematic use of countries as units of analysis. Padovani and Scorsone (2009) discuss the particular problems of finding precise ways to measure performance at the local government level internationally.

Recognizing these limits, what is our position? This study is based on an understanding of social conditions and social change as being multidimensional, involving economic, political, social and cultural dimensions, which interact in complex ways. Care for older people encompasses a complex research area that requires an interdisciplinary approach and the use of several methodological approaches. We argue that research in this field may take advantage of being based on, and integrated in, interdisciplinary theoretical frameworks and methodologies. This combination of approaches makes it difficult to adhere to a strict research design, but it also makes it possible to collect more sensitive and nuanced data in order to picture a multifaceted reality. The study relies on the method of cross-national policy comparison. Because of the study's comparative nature, it is to a large extent descriptive and explorative. Norway has strong and long-standing social-democratic institutions, while Latvia and Lithuania have not developed similar institutions. These two countries should be regarded as young, liberal democracies that in addition share a common history of having been under Soviet rule from the early 1940's until 1991. These differences make it pertinent to study the norms that influence the decisions of employees in care for older people.

Figure 1: A Multidimensional Design

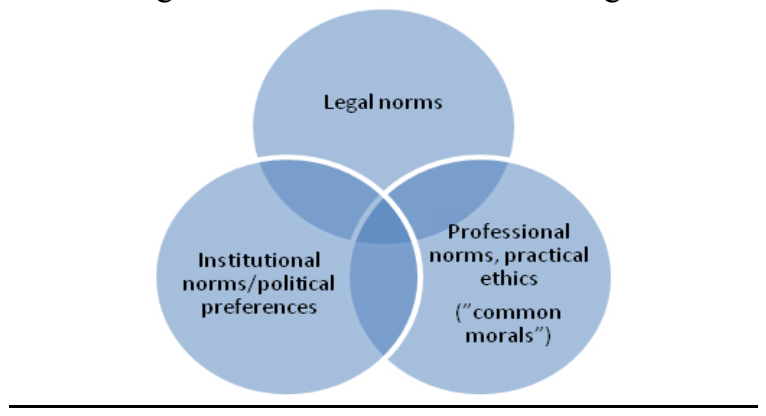

Source: Authors' own figure. 


\subsection{Legal Norms}

This category comprises legal norms and governmental directives about care for older people. It includes both health care and social care. Legality is used to categorize items in our data that signify considerations of rightful treatment of people, how complaints are being treated, how rules and by-laws are used, the legal rights of the individual, and appropriate spending of money.

\subsection{Institutional norms}

Municipal and administrative instructions, and internal rules about care and services for older people include issues of housing, health treatment, social and economic needs; public versus private and home-based versus institutional care; user participation etc.). Performance measurement and strategic, financial, operational, and human resource planning are used to carry out these processes.

\subsection{Professional norms and practical ethics}

Professional and ethical norms guide front-line administrators in conducting qualified professional work within care for older people. Professionalism here means ethical behavior according to accepted professional values (guidelines), in contrast to private ideas of fair treatment of people (Lundquist, 1998).

\section{METHOD/DATA SOURCES}

The interviews in this study were conducted in 2010 and 2011; the same goes for the main part of other material although some documents are older.

1) Documentary analysis of national legislation and policy documents for each country

2) Structured and semi-structured interviews based on vignettes designed to elicit responses relevant to the study

3) Factor analysis and multiple sample tests of the quantitative part of the questionnaire.

\subsection{Respondents}

The participants in the study were selected by purposive sampling of professional social and health workers in urban as well as rural municipalities in each country. While we aimed at 40 respondents from each country, the actual total of 109 includes 39 Latvians, 27 Lithuanians, and 43 Norwegians. Most respondents have at least a bachelor degree in social work, nursing or related fields. Some, especially in Norway, had additional degrees in management. Practically all were women. The number of municipalities included from each country reflects their relative sizes: Latvia 9, Lithuania 3, and Norway 5. The interviews were conducted in 2010 and 2011.

\subsection{The Vignette Method}

Vignettes or scenarios are described as brief cases that simulate real events depicting hypothetic situations (Wilks, 2004). The vignettes should present participants with real-life decision-making situations. Effective vignettes are those with which participants can identify (Soydan \& Stål, 1994; Jergeby, 2008). In research, vignettes may be used to explore practices focusing on responses to hypothetical situations and may facilitate study of sensitive areas of enquiry (Barter \& Renold, 1999). 
The most frequently identified limitations to vignette studies are related to the distance between the responses to vignettes and social reality, since there is no guarantee that the responses will mirror the behavior of the respondents in their professional practice (Eskelinen \& Caswell, 2006; Wilks, 2004:82). However, in this study the vignettes create an important shared point of departure and may reveal differences in approach that could be attributed to institutional and social contexts (Soydan, 1995; 1996; Eskelinen \& Caswell, 2006). The two vignettes in this study include one case originally from Latvia and the other from Norway. The vignettes describe authentic cases that could have happened in all three countries.

\subsection{Vignette Content}

Both vignettes concern families in desperate straits. The first vignette describes the situation of an elderly couple with health problems, who needs help from the social services. Due to economic problems, the municipality has to reduce its expenditures, and it is uncertain whether the elderly couple will get the help they need.

The second vignette presents a story about a social worker, who in following up a case of child neglect in a broken family, comes across a 78-year-old man living under depressing conditions. He obviously needs help from the social services and the social worker has motivated him to apply for home care. Encountering minor problems with documentation of his situation, the old man gives up and withdraws his application.

\subsection{Interviews based on the vignettes}

The vignettes served as the basis of qualitative interviews with frontline administrators, e.g. professionals that presumably make assessments of needs for older people with respect to home-based assistance or placement in a nursery home. These public administrators are usually expected to meet the elderly persons and their families face to face. Their assessments of the situations described in the vignettes were also collected in the quantitative part of the questionnaire that asked the respondents to give answers to various normative statements. The same interview guide was used in all three countries translated into their respective languages: Latvian, Lithuanian, and Norwegian

The process started by asking the respondents to read carefully the vignette stories before answering the questions. In the qualitative part of the interviews, the respondents received a questionnaire on how they would act in the different situations. What decisions they would have made and about the values and norms, their decisions primarily were based on.

\subsection{Considerations in Deciding Individual Cases}

The quantitative section of the questionnaire had two parts. The first part asked respondents to rate possible considerations that they thought important in deciding a course of action in the two cases described in the vignettes. After a thorough reading of the vignettes, the respondents were asked to rate each of eleven statements with high or a low number according to their agreement or disagreement with each. Any number was acceptable, but respondents were told that the number 50 indicated neither agree nor disagree. The statements measure different norms of action that the interviewee displays when she/he considers what solutions should be made in the vignette story. How much discretionary power does the individual respondent feel that he or she has as opposed to legal and institutional norms? This discretionary power of social and health professionals is analyzed in terms of what we have labeled as professional norms and practical ethics.

The items of the questionnaire were put in random order. For analytical purposes, we conducted a factor analysis to determine possible underlying relationships between them. The 
results of this analysis produced four components or factors that have been used in categorizing the variables in the tables in this section. For practical purposes, the Norwegian data were chosen for this analysis since they provided the clearest categorization of the questionnaire items.

\section{Vignette 1}

The Old Couple

[In the translations, common national names were used instead of the English names used here]

The story of John and Mary concerns the situation of an elderly married couple. The two have for a long time struggled with their daily life. They are both retired. John was earlier a bank employee, Mary was a housewife. They have a decent pension, they have always been cautious in using money, and they have a small but tidy fortune in the form of a bank deposit.

During the last few years John has had problems with his heart, but he manages reasonably well. Mary's health is worse. During the last 10 years she has more and more suffered from dementia, she forgets things, when she is going for a walk it happens that she enters the wardrobe and does not know how to get out. She wants to help John with practical matters, and some days ago she would light a fire in the stove, but the result was that she made an open fire in the middle of the floor.

Both of them feel desperate, and although none of them wants it, they have now turned to the municipality and asked for help. What they have in mind is that Mary can move to a nursing home, or at least might stay there some days a month. The family doctor has in a letter to the local government administration documented that admission to the nursing home is absolutely necessary.

Mary and John have three children living in the neighborhood, but they have only regular contact with one of them; their daughter and her husband. Both work full time, the son- in- law is a shift worker and their daughter helps in a clothes shop.

The municipality where they are living has severe economic problems. A serious deficit is expected this year, if no action is taken. The administrator of the nursing home has been ordered to reduce the expenditures drastically, and daily she has controversies with the welfare worker who wants patients registered.

\section{Vignette 2}

The Case of the Single Old Person

[In the translations, common national names were used instead of the English names used here.]

The Family Court [Norway: Fylkesnemnda] has initiated a case to suspend the parental responsibility of Anna to her three-year old son Alex. Anna is an alcoholic without permanent residence moving with her son from place to place. The woman is divorced and does not have any contacts with Ivar, the boy's father. The Family Court has sent a letter to the Social Service Centre with a request to check the father's ability and preparedness to take care of his son.

A social worker from the family unit made a visit to the address where Ivar is supposed to live, but she didn't find Ivar there. Instead, the social worker met a neglected old person living in the flat. It was Peter, Ivar's father. [It was Helena, Ivar's mother]. 
Peter [Helena] is 78 years old. Household conditions in the flat are depressing; it is dirty, the cooking stove and the toilet don't work, and the telephone has been disconnected. The only communication channel with the outside world is an old TV set. Peter's pension goes to pay the rent. To earn additional income, he collects and sells empty bottles, and buys bread for the money he gets. Peter neither smokes nor uses alcohol. Peter's wife died two years ago, and since then he is depressed and doesn't like to communicate with other people.

Peter visited the Social service centre some years ago and asked for help there, but he didn't get any. The Social worker said then that Peter's son could take care of him. Peter now says that he doesn't need any help, but the visiting social worker motivated the old man to meet a social worker from the unit for adults. The social worker should make an inspection of the flat and evaluate Peter's need for home services (to buy food, to put the house in order, and to help with hygiene). The old man agreed to do that.

The social care worker visited Peter and asked him to fill in an inquiry form and a declaration of needs and possibilities to get home care. In accordance with requirements, Peter had to provide some papers from the house-manager's office. After the visit of the social worker Peter changed his mind and took back his application for assistance. In the opinion of the social worker, Peter is capable to take of himself. The case was closed.

\section{RESULTS}

The results of the vignette study show that case workers in Latvia and Lithuania will consider providing care for older people through the local authority only as a last resort. This means when the elderly can no longer cope by themselves or with the help of their families, while Norwegians hardly consider at all what the family might be able to do. Based on the factor analysis the items of the questionnaire are categorized according to relevant components (factors). Component 1 includes two of the concepts in our multidimensional design shown in Figure 1, while components 3 and 4 are covered by the third concept of institutional norms. For the sake of convenience, we have labeled the relevant components as follows:

1. Importance of laws, regulations, and professional norms

2. Importance of personal relationships at work

3. Economic constraints

4. Administrative constraints.

The survey results show some similarities, but also substantial differences in what the social and health workers regard as relevant concerns in deciding individual cases of elderly care in their respective countries. Additionally, they consider relationships to other people and limits to economic and administrative capacities as important considerations in making decisions in each case as depicted in the two vignettes used here. A systematic analysis shows these differences:

Component 1: "Laws, regulations and professional norms". Lithuanians and Norwe-gians are more alike in their ranking of concerns on factors of this component. They give higher rank than Latvians to "my plan of action needs to be rational and strive for the equal treatment of all", to "respect for the authority of law is part of one's obligation to society", to "I must show respect for the viewpoint of citizens in determining what services to provide", and "it is important for me to contribute to a better society". In conclusion, it appears that 
Lithuanian and Norwegian respondents adhere closer to Max Weber's (1964) ideal of the rule-oriented civil servant, who ignores her own self-interest.

Table 1. Relevant concerns in deciding cases in elderly care. Average scores of respondents in each country. Ranked according to results of factor (principal component) analysis of Norwegian cases. $\mathrm{N} \approx 101$.

\begin{tabular}{|c|c|c|c|c|}
\hline & Norway & Latvia & Lithuania & $\mathrm{p}$ \\
\hline \multicolumn{5}{|l|}{$\begin{array}{l}\text { Component 1: "Laws, regulations } \text { and } \\
\text { professional norms" }\end{array}$} \\
\hline $\begin{array}{l}\text { My plan of action need to be rational and strive } \\
\text { for the equal treatment of all. }\end{array}$ & 82.6 & 67.7 & 81.8 & $* *$ \\
\hline $\begin{array}{l}\text { I must show respect for the values of my } \\
\text { profession is part of my training. }\end{array}$ & 86.0 & 78.2 & 77.7 & \\
\hline $\begin{array}{l}\text { Respect for the authority of law is part of one's } \\
\text { obligation to society. }\end{array}$ & 81.5 & 66.4 & 77.4 & $* *$ \\
\hline $\begin{array}{l}\text { I feel compassion for people in need and must do } \\
\text { well for our clients. }\end{array}$ & 78.0 & 71.2 & (62.8) & $*$ \\
\hline $\begin{array}{l}\text { I must show respect for the viewpoint of citizens } \\
\text { in determining what services to provide. }\end{array}$ & 80.5 & 63.7 & 69.6 & ** \\
\hline $\begin{array}{l}\text { It is important for me to contribute to a better } \\
\text { society. }\end{array}$ & 72.1 & 67.7 & 78.2 & \\
\hline \multicolumn{5}{|l|}{ Component 2: "Personal relationships at work" } \\
\hline $\begin{array}{l}\text { I have to maintain good relations with other } \\
\text { people involved in this case. }\end{array}$ & 60.3 & 65.7 & 66,6 & \\
\hline $\begin{array}{l}\text { I have to maintain long-term relationships with } \\
\text { other people to get along. }\end{array}$ & 49.3 & 71.9 & 64.0 & $* *$ \\
\hline I can be punished for making the wrong decision. & 39.4 & 61.1 & 39.7 & $* *$ \\
\hline \multicolumn{5}{|l|}{ Component 3: "Economic constraints" } \\
\hline $\begin{array}{l}\text { I have to accept economic limits to what we can } \\
\text { do in this case. }\end{array}$ & 56.6 & 68.0 & 54.8 & $*$ \\
\hline \multicolumn{5}{|l|}{ Component 4: "Administrative constraints" } \\
\hline $\begin{array}{l}\text { I have to accept the actual ability of my office to } \\
\text { carry out this task. }\end{array}$ & 65.4 & 68.0 & 78.9 & \\
\hline
\end{tabular}

Source: Authors' compilation

Note: Scores higher than 50 indicate support or agreement with the statement. Scores below 50 indicate disagreement. Varying $n$ for each statement.

p: Kruskal-Wallis Multiple Sample Test for comparing distributions across multiple groups.

** Answers are significantly different at the $\mathrm{p}<0.01$ level

* Answers are significantly different at the $\mathrm{p}<0.05$ level

(62.8): Less than ten cases.

Component 2: "Personal relationships at work". "Maintain(ing) good relations with other people" seems to be regarded as equally important considerations by all three groups. The Latvian respondents differ from the two others by regarding "maintain long-term relationships with other people to get along" as more important than the two other groups. 
Latvians also tend to score highest with regard to "I can be punished for making the wrong decision". Again, it appears that the Norwegian and Lithuanian respondents adhere closer to Max Weber's ideal of the rule-oriented civil servant, who can make (independent) decisions with-out considering personal relationships at work as relevant concerns (Weber 1964).

Component 3: "Economic constraints". Given the economic problems and budget reductions facing Latvia and Lithuania at the time of the survey, one might expect that that limits to spending appeared as a major concern in deciding cases of elderly care in Latvia and Lithuania, compared to Norway. As one can see from component 3 in table 1, this was not the case. Respondents in Lithuania and Norway were both less concerned with "economic constraints" than the Latvians.

Component 4: "Administrative constraints". On the other hand, the results displayed in component 4 indicate that Lithuanian respondents were more concerned than the two others about "the actual capacity of my office to carry out this task".

Tables $1-4$, above and below, are composed of the items of the questionnaire and categorized according to relevant components (factors).

In this investigation of concerns in decision-making, we sought to analyze in more depth the variation in viewpoints among the respondents according to their national background. In particular, we considered whether the apparent differences in table 1 can be shown to be statistically significant even though the samples are relatively small. In order to do this, three multi-sample tests were conducted, one for each country sample. The results of these tests are indicated by the stars in the last column of table 1 .

The Kruskal-Wallis test used to detect differences between the results from Latvia, Lithuania, and Norway, shows significant variations between the three countries regarding the following variables:

- I must show respect for the viewpoint of citizens in determining what services to provide (Component 1)

- $\quad$ My plan of action needs to be rational and strive for the equal treatment of all (1).

- $\quad$ Respect for the authority of law is part of one's obligation to society (1).

- I feel compassion for people in need and must do well for our clients (1).

- I have to maintain long-term relationships with other people to get along (2).

- $\quad$ I can be punished for making the wrong decision (2).

- I have to accept economic limits to what we can do in this case (3).

It might have been expected that the differences in the main would involve Norway in contrast to the two Baltic countries, but as shown by the numbers in table 1, there were major differences between the Latvian and Lithuanian groups as well. The Latvian respondents concern themselves more than the other two groups with the risk of punishment for wrong decisions, while putting less emphasis on rational plans of action and the ability of the office to carry out its tasks. In these respects, the Lithuanian case workers are more similar to their Norwegian colleagues.

For the remaining four variables there are no significant differences between the three groups of respondents:

- I must show respect for the values of my profession that is part of my training (Component 1).

- $\quad$ It is important for me to contribute to a better society (1).

- I have to maintain good relations with other people involved in this case (2).

- $\quad$ I have to accept the actual ability of my office to carry out this task (4). 
Table 2. Concerns in deciding cases in care for older people. Average scores for each category of component variables reported in table 1 .

\begin{tabular}{|l|r|c|c|}
\hline & Norway & \multicolumn{1}{l|}{ Latvia } & Lithuania \\
\hline Component 1: "Laws, regulations and professional norms" & 80,1 & 69,2 & 74,6 \\
\hline Component 2: "Personal relationships at work” & 49,7 & 66,2 & 56,8 \\
\hline Component 3: "Economic constraints" & 56.6 & 68.0 & 54.8 \\
\hline Component 4: “Administrative constraints" & 65.4 & 68.0 & 78.9 \\
\hline
\end{tabular}

Source: Authors' compilation.

Note: Scores higher than 50 indicate average support or agreement with the statements included in the component. Scores below 50 indicate disagreement. $\mathrm{N} \approx 101$.

To provide a clearer impression of the implications of this study, the survey data were further consolidated in table 2, which shows the average total scores of the original variables included in each component. The numbers shown in table 2 can, depending on the circumstances, be seen to reinforce or contradict each other in decisions made about care for older people. While components 3 and 4 clearly put restrictions on what a public administrator may decide, this might not be so obvious in the case of components 1 and 2 . However, Norwegian professionals seem more concerned with following laws and regulations than in maintaining good relationships with other people at work. For Latvians in particular, sympathetic relations with colleagues rank at the same level in importance as following formal rules.

Table 3. Relevant concerns in deciding cases in elderly care. Average scores of respondents in each country. Ranked according to stages of ethical reasoning.

\begin{tabular}{|c|c|c|c|c|}
\hline & Norway & Latvia & Lithuania & $p$ \\
\hline 1. I can be punished for making the wrong decision. & 39.4 & 61.1 & 39.7 & $* *$ \\
\hline $\begin{array}{l}\text { 2. I have to maintain good relations with other people } \\
\text { involved in this case. }\end{array}$ & 60.3 & 65.7 & 66,6 & \\
\hline $\begin{array}{l}\text { 3. I have to maintain long-term relationships with other } \\
\text { people to get along. }\end{array}$ & 49.3 & 71.9 & 64.0 & $* *$ \\
\hline $\begin{array}{l}\text { 4. Respect for the authority of law is part of one's } \\
\text { obligation to society. }\end{array}$ & 81.5 & 66.4 & 77,4 & $* *$ \\
\hline $\begin{array}{l}5(\mathrm{P}) \text {. My plan of action needs to be rational and strive } \\
\text { for the equal treatment of all. }\end{array}$ & 82.6 & 67.7 & 81,8 & $* *$ \\
\hline
\end{tabular}

Source: Authors' compilation.

Note: Scores higher than 50 indicate support or agreement with the statement. Scores below 50 indicate disagreement. Varying $n$ for each statement. $\mathrm{N} \approx 101$.

Kruskal-Wallis Multiple Sample Test for comparing distributions across groups:

** Answers are significantly different at the $p<0,01$ level. 
Table 3 shows items from the questionnaire ranked according to the stage model of moral reasoning developed by Debra Stewart and associates (1997) with 5 (P) as the most principled or universal stage. In this study, we see that both Lithuanian and Norwegian case workers score high with regard to concern 4, "respect for the authority of law...", and 5, "my plan of action needs to be rational..." On the other hand, Latvians score lower on both variables, but provide more support to concern 3 "to maintain long-term relationships with other people to get along".

These findings accord with other observations of administrative reform in the new democracies of Central Eastern Europe. Latvia and Lithuania were among the first countries to adopt new civil laws in the 1990s. New laws require implementation, but according to the World Bank (2006) Latvia and Lithuania were among the most successful in limiting politicization of the civil service. However, other problems may remain regarding everyday informal practice, low wages, and shortages of resources for training and equipment (Neshkova \& Kostadinova, 2012).

\subsection{Attributes of the Place to Work}

The second section of the quantitative part of the questionnaire measured respondents' different attitudes to various attributes of their work environment. The statements are not directly related to the content of the vignettes but have a strong relevance to the variables rated in the previous section. In this second part, as in the first, the respondents were asked to do a similar rating of items about various aspects of their place of work.

The results in table 4 show that case workers in Latvia, Lithuania, and Norway largely agree on matters that pertain to the quality of management at their agencies (Component 1). On average they tend to agree to the ready-made statements regarding supervision, collegiality, and autonomy. It is tempting to conclude that people who work in elderly care share a common management culture in all three countries. However, looking at the variables included in components 2 and 3, there are significant differences between the responses from the three countries. These differences show up particularly in regard to pay, opportunities for innovation, how much effort the respondent applies to his job, and how challenging the work is. Norwegian respondents are more likely to say that they find their jobs both challenging and requiring hard effort.

With regards to the rewards of work, Brehm and Gates (1997: 74-75) distinguish between economic, functional, and what they call "solidary" rewards. Economic rewards can include wages, fringe benefits, vacations and similar payments, but in this particular study we have only included one item where the respondents have been asked to compare their pay in comparison with other people in their agency. The Lithuanians are the most dissatisfied, followed by the Norwegians. In this case we are not considering objective differences in pay, rather relative deprivation compared to other individuals or groups.

Functional rewards involve drawing satisfaction from performing "the very things that he is supposed to do" (Brehm \& Gates, 1997: 74). Several items in table 4 indicate relatively high job satisfaction with the functional aspects of elderly care, particularly in the high support given to the statement that "Doing my work well gives me a feeling that I've accomplished something worthwhile." In contrast is the dismay felt by many in Latvia that "It's not really possible to change things around here."

The professionals are in general satisfied with their colleagues' willingness to cooperate and with their skills and abilities. Job satisfaction evidently compensates for dissatisfaction with monetary rewards, since most respondents express satisfaction with the general work situation. 
Table 4. Aspects in the evaluation of respondents' work environment. Average scores of respondents in each country. Ranked according to results of factor (principal component) analysis of all cases.

\begin{tabular}{|c|c|c|c|c|}
\hline & $\begin{array}{l}\text { Latvia } \\
(\mathrm{n}=39)\end{array}$ & $\begin{array}{c}\text { Lithuania } \\
(\mathrm{n}=27)\end{array}$ & $\begin{array}{c}\text { Norway } \\
(\mathrm{n}=43)\end{array}$ & $p$ \\
\hline \multicolumn{5}{|l|}{ Component 1: "Management quality" } \\
\hline I have confidence and trust in my organization. & 77.4 & 76.0 & 76.3 & \\
\hline $\begin{array}{l}\text { My supervisor and I agree on what "good performance" } \\
\text { on my job means. }\end{array}$ & 71.6 & 66.6 & 70.8 & \\
\hline People in my work unit cooperate to get the work done & 77.5 & 76.4 & 78.3 & \\
\hline $\begin{array}{l}\text { My co-workers have the necessary skills and abilities to } \\
\text { perform their jobs }\end{array}$ & 72.7 & 73.1 & 74.4 & \\
\hline My supervisor works well with people & 76.0 & 81.4 & 72.9 & \\
\hline My job performance is carefully evaluated by my superior. & 70.0 & 65.1 & 60.9 & \\
\hline $\begin{array}{l}\text { In general, disciplinary actions taken in this office are fair and } \\
\text { justified. }\end{array}$ & 69.2 & 61.6 & 59.5 & $*$ \\
\hline I have a great deal of say over what has to be done on my job. & 72.2 & 66.6 & 66.1 & \\
\hline \multicolumn{5}{|l|}{ Component 2: "Job satisfaction" } \\
\hline $\begin{array}{l}\text { Doing my work well gives me a feeling that I've } \\
\text { accomplished something worthwhile. }\end{array}$ & 74.8 & 74.7 & 85.3 & $*$ \\
\hline It's not really possible to change things around here. & 63.3 & 41.5 & 33.5 & $*$ \\
\hline My work responsibilities are challenging. & 55.8 & 57.6 & 80.9 & $*$ \\
\hline \multicolumn{5}{|l|}{ Component 3: "Economic rewards" } \\
\hline $\begin{array}{l}\text { I am satisfied with my pay, considering what people in similar } \\
\text { jobs in this agency are paid }\end{array}$ & 71.8 & 37.4 & 54.9 & $*$ \\
\hline \multicolumn{5}{|l|}{ Unclassified variables } \\
\hline In general I like to work here. & 74.4 & 73.6 & 80.8 & \\
\hline I work hard on my job & 69.6 & 47.0 & 83.9 & * \\
\hline
\end{tabular}

Source: Authors' compilation.

Note: Scores higher than 50 indicate support or agreement with the statement. Scores below 50 indicate disagreement. Varying $n$ for each statement. Total: $\mathrm{N}=109$.

p: Kruskal-Wallis Multiple Sample Test for comparing distributions across groups.

** Answers are significantly different at the $\mathrm{p}<0.01$ level

$*$ Answers are significantly different at the $\mathrm{p}<0.05$ level

\section{CONCLUSION}

The results of the qualitative study reported earlier, showed that case workers in Latvia and Lithuania will consider providing care for older people through the local authority only as a last resort. This difference might has to do with norms imbedded both in their professional role and in laws about care in the three countries.

In making their decisions, the interviewees differ from the Weberian ideals of being rational, law-abiding, and treating everybody as equals. In this regard professionals in Latvia stand out as being less rule-oriented than Lithuanians and Norwegians. The findings suggest 
that the Norwegian interviewees more often than the Latvians and the Lithuanians experience ethical dilemmas between professional values and respect for the viewpoint of citizens.

Guogis and Koht (2009) have shown that Lithuania and Norway are not likely to develop similar social policies for fundamental political reasons. This article shows that this conclusion can even be applied to Latvia, where also adult children are regarded as providers of primary help to their elderly parents. While Lundquist (1998) considers that the public ethos implies the balancing of democratic and economic values, this study shows that for public administrators other ethical issues can be just as imperative. Maintaining good relationships with other people involved in the single cases, had a high priority in all countries. However, in the Latvian case (table 3) there appears no clear-cut expression of a common public ethos, thereby increasing the risk of arbitrariness in individual cases. Of the three countries, Latvia has the least professionalized service together with a strong emphasis on teamwork. Teamwork, however, might balance the risk of arbitrariness and even improve the way complex situations are handled, as argued by Leichsenring, Billings and Nies (2013). A later study might attempt to work out whether this argument holds for Latvia.

Lithuanian and Norwegian administrators express their public ethos by adhering to democratic values based on the rule of law, their Latvian colleagues to a larger extent are faced with the dilemma of choosing between democratic and economic values.

Latvia went through a radical reduction of the number of its municipalities from 225 to 118 in 2009 in order to optimize both organizational structure and budgets. This reform, together with an improved economic situation, will expectedly lead to improvements in local administration, including services to a growing number of elderly. This will require the recruitment of case and care workers who are confident in making client-oriented decisions without fear of repercussions.

Briefly summarized, in all three countries the professionals take a stepladder approach in considering plans of action in each of these vignette cases. From home-based visits and care as the first step and placement in a nursing home as the last. While professionals in Latvia and Lithuania are required to look for possible assistance from other family members - even neighbors - as a first priority, this policy does not apply to Norway. Here children of the elderly may appear more as lobbyists on their behalf. In making their decisions, the public servants in all countries emphasize the necessity of considering a broad range of legal and professional norms. For all respondents these considerations - in varying degrees of intensity - rank ahead of economic and administrative concerns. This finding suggests that several interrelated and overarching professional norms make up the core of care for older people in all three countries: to respond to the person in need, to respect the dignity of people, and to follow legal procedures.

\section{ACKNOWLEDGMENTS}

This article presents results from the research project Challenges from an Aging Population that involved researchers from Østfold University College, Norway; Oslo and Akershus University College of Applied Sciences, Norway; Latvia University, Latvia; Vytautus Magnus University, Lithuania; and Mykolas Romeris University, Lithuania.

The editors would like to thank Maria Wolmesjö (Ph.D) at Lindköping University, Sweden, and Lars Zanderin (Ph.D) at Linnéus University, Sweden, who participated from the start of the project. At the final stage of the project the editors decided that the comparative perspectives of the study would be easier to frame using data from only three countries, 
Latvia, Lithuania and Norway. Special debts of gratitude are owed to Faculty of Business, Languages and Social Sciences at Østfold University College, and to Faculty of Social Sciences at Oslo and Akershus University College for their support to the project.

\section{REFERENCES}

BARTER, C. and RENOLD, E. (1999). "The Use of Vignettes in Qualitative Research". Social Research Update, 25 (25): 1-6.

BREHM, J. and SCOTT, G. (1997). Working, Shirking, and Sabotage: Bureaucratic Response to a Democratic Public. Ann Arbor: University of Michigan Press.

DAATLAND, S. O. (1997). Social Protection for the Elderly in Norway. Oslo: Norwegian Social Research.

DWORKIN, G. (1988). The Theory and Practice of Autonomy. Cambridge: Cambridge University Press.

ERIKSEN, E. O. (2001). Demokratiets sorte hull - om spenningen mellom fag og politikk Ivelferdsstaten [The Big Hole of Democracy: the Tension Between Professions and Politics in the Welfare State]. Oslo: Abstrakt.

ESKELINEN, L. and CASWELL, D. (2006). "Comparison of Social Work Practice in Teams Using a Video Vignette Technique in a Multi-Method Design". Qualitative Social Work, 5: 489-503.

FITZPATRICK, J.; GOGGIN, M.; HEIKKILA, T.; KLINGNER, D.D.; MACHADO, J. and MARTELL, C. (2011). "A New Look at Comparative Public Administration: Trends in Research and an Agenda for the Future". Public Administration Review, 71 (6): 821-830.

GREGERSEN, F. A. and MELBERG, H. O. (2014). "I hvorstor grad vil eldrebølgen bidra til økte helsekostnader? En studie av ulike framskrivningsmetoder for helsekostnader" [How will the increase in the elderly population contribute to higher health costs?]. Samfunns $\phi$ konomen, 128 (7): 22-38.

GUOGIS, A. and KOHT, H. (2009). "Why not the Nordic Welfare State Model in Lithuania? Trends in Lithuanian and Norwegian Social Policies". In J. Aidukaite (Ed.) Poverty, Urbanity and Social Policy. New York: Nova Science Publishers, pp. 149-167.

HYDÉN, H. (2011). "Looking at the World through the Lenses of Norms: Nine Reasons for Norms: a Plea for Norm Science". In K. Popendorf; S. Machura, and K. Andenæs (Eds.) Understanding Law in Society: Developments in Socio-Legal Studies. Münster: LIT Verlag, pp. 120-159.

JERGEBY, U. (2008). Evidensbaserad praktik $i$ socialt arbete [Evidence-Based Practice in Social Work]. Socialstyrelsen. Institut för utveckling av metoder i socialt arbete. Stockholm: Gothia IMS.

KILDAL, N. and KUHNLE, S. (2005). Normative Foundations of the Welfare State: The Nordic experience. Oxon: Taylor \& Francis.

KJØRSTAD, M. (2005). "Between Professional Ethics and Bureaucratic Rationality: the Challenging Ethical Position of Social Workers Who Are Faced with Implementing a Workfare Policy". European Journal of Social Work, 8 (4): 381-398.

KJØRSTAD, M. (2008). "Opening the Black Box: Mobilizing Practical Knowledge in Social Work", Qualitative Social Work, 7 (2): 143-161.

LEICHSENRING, K.; BILLINGS, J. and NIES, H. (2013). Long-term care in Europe. Improving policy and practice. Houndmills, Basingstoke: Palgrave Macmillan.

LODGE, M. (1981). Magnitude Scaling: Quantitative Measures of Opinion. Beverly Hills: Sage.

LUNDQUIST, L. (1988). Byråkratisk etik [Bureaucratic Ethics], Lund: Studentlitteratur,.

LUNDQUIST, L. (1992). Forvaltning, stat och samhälle [Administration, State and Society], Lund: Studentlitteratur.

LUNDQUIST, L. (1998). Demokratins väktare [The Guards of Democracy]. Lund: Studentlitteratur.

LUNDQUIST, L. (2001) "Etik och förvaltning" [Ethics and Administration]. In B. Rothstein (Ed.) Politik som organisation. Förvaltningspolitikens grundproblem [Politics as organization: The foundational problem of public administration]. Stockholm: SNS Förlag. 
NESHKOVA, M. I. and KOSTADINOVA, T. (2012). "The Effectiveness of Administrative Reform in New Democracies". Public Administration Review, 72 (3): 324-333.

MCCRAE, R. R., and JOHN, O.P. (1992). "An Introduction to the Five-Factor Model and its applications". Journal of Personality, 60 (2): 175-215.

PADOVANI, E. and SCORSONE, E. (2009). "Comparing Local Governments' Performance Internationally: a Mission Impossible?" International Review of Administrative Sciences, 75 (2): 219237.

RAWLS, J. (1993). Political Liberalism. New York: Columbia University Press.

ROTHSTEIN, B. (1998). Just Institutions Matter: the Moral and Political Logic of the Universal Welfare State. Cambridge: Cambridge University Press

ROTHSTEIN, B. (2001). Politik som organisation. Förvaltningspolitikens grundproblem [Politics as Organization]. Stockholm: SNS Förlag

SKDS. (2012). Iedzīvotāju drošības sajūta. Latvijas iedzīvotāju aptauja. 2012.gada februāris.[Sense of Security of Citizens. The Survey of Citizens in Latvia. February 2012.] Rīga: SKDS.

SØRENSEN, R. J. (2009). "Hvordan påvirker eldrebølgen de offentlige budsjett-prioriteringene?" [How does the increased population of elderly affect public budgetary priorities?]. Lecture at a conference organized by the Statistical Reports Committee for County and Municipal Government Finance. Oslo. https://www.regjeringen.no/.../hvordan_paavirker_eldrebolgen_de_offen

SOYDAN, H. (1995). "A Cross-Cultural Comparison of How Social Workers in Sweden and England Assess a Migrant Family”. International Journal of Social Welfare, 4 (1): 85-93.

SOYDAN, H. and STÅL, R. (1994). "How to Use the Vignette Technique in Cross-Cultural Social Work Research". International Journal of Social Welfare, 3 (1): 75-80.

SPICKER, P. (1995) Social Policy: Themes and Approaches. London: Prentice Hall,.

STEWART, D. W.; SPRINTHALL, N. and SIEMIENSKA, R. (1997) "Ethical Reasoning in a Time of Revolution: a Study of Local Officials in Poland". Public Administration Review, 57 (5): 445-453.

SVARA, J. H. (2014). "Who Are the Keepers of the Code? Articulating and Upholding Ethichal Standards in the Field of Public Administration". Public Administration Review, 74 (5): 561-568.

TAYLOR, I. and KELLY, J. (2006). "Professionals, Discretion and Public Sector Reform in the UK: Re-Visiting Lipsky”, International Journal of Public Sector Management, 19 (7): 629-642

TRANØY, K. E. (1998). Det åpne sinn. Moral og etikk mot et nytt årtusen. [The Open Mind: Morals and Ethics towards a New Millenium]. Oslo: Universitetsforlaget.

WEBER, M. (1964). Die drei reinen Typen der Legitimen Herrschaft [The Three Types of Legitimate Rule]. In Soziologie. Weltgeschichtliche Analysen. Politik. 3rd edition. Stuttgart:Alfred Kröner Verlag, pp. 151-166.

WEST'S ENCYCLOPEDIA OF AMERICAN LAW. (2004). S.v. administrative discretion; abuse of discretion; discretionary action.

WILKS, T. (2004). "The Use of Vignettes in Qualitative Research into Social Work Values". Qualitative Social Work, 3: 78-87.

WORLD BANK. (2006). EU-8 Administrative Capacity in New Member States: The Limits of Innovation? Report no. 36830-GLB. Washington, DC: World Bank. 


\section{Breve currículo:}

\section{Monica Kjørstad,}

Monica Kjørstad (Ph.D), associate professor at Oslo and Akershus University College of Applied Sciences. Monica Kjørstad's field of research is social work and social policy. She teaches courses of social administration and planning, management, ethics, social work and human rights and the theory of science. Her research interests focus on social welfare policies, implementation practices and social work ethics.

\section{Harald S. Koht,}

Harald S. Koht (Ph.D) is a professor of political science at Oslo and Akershus University College of Applied Science. He received his $\mathrm{PhD}$ in public administration at American University in Washington, DC. He was EuroFaculty visiting lecturer at the University of Latvia in 2000-02. His scientific articles cover a broad range of topics including local government, citizen participation, and public administration reform in Norway and Latvia.

\section{Iveta Reinholde}

Iveta Reinholde (Ph.D.), associate professor of political science. Iveta Reinholde teaches courses on public administration and policy analysis at University of Latvia. Mainly, Iveta Reinholde is researching public administration reform and public management issues in Latvia. Her research interests focus on policy transfer, governance and EU impact on national public administration.

\section{Geir C. Tufte}

Geir C. Tufte, associate professor of political science. Geir C. Tufte teaches courses of political science at Østfold University College, Norway. He has for several years done research on local democracy and local welfare services, mainly on Norwegian municipalities. The last ten years his research has also encompassed municipalities in Latvia, Lithuania, Poland and Sweden together with academics from these countries. 